\title{
Peripheral T cell lymphoma in Asia
}

\author{
Sanghui Park $\cdot$ Young Hyeh Ko
}

Received: 9 December 2013/ Accepted: 15 January 2014/Published online: 31 January 2014

(C) The Japanese Society of Hematology 2014

\begin{abstract}
Peripheral T-cell lymphomas (PTCLs) comprise a heterogeneous group of mature T- and NK-cell neoplasms, the incidence of which is higher in Asian countries than in Western countries. Although its etiology is mainly unknown, several risk factors (such as genetic factors, abnormal immunity, environmental factors, and infectious causes) have been proposed. PTCL are classified based on a combination of several parameters, including morphology, site of presentation, viral status, immunophenotype, and specific genetic alterations. Their classification is ongoing, with the emergence of new entities and refinement of existing entities because of the development of diagnostic markers and new genetic alterations. This review presents epidemiologic data for PTCL in Asia, together with recent progress in the pathology of PTCL compared with the WHO 2008 classification.
\end{abstract}

Keywords Malignant lymphoma $\cdot \mathrm{T}$ cell $\cdot$ Asia . Epidemiology $\cdot$ Pathology

\section{Epidemiology}

T- and NK-cell lymphomas are uncommon: overall, they represent fewer than $25 \%$ of all non-Hodgkin's lymphoma

\section{S. Park}

Department of Pathology and Global Top 5 Research Program, Ewha Womans University School of Medicine, Seoul,

Republic of Korea

\section{Y. H. Ko ( $\square)$}

Department of Pathology, Samsung Medical Center,

Sungkyunkwan University School of Medicine, 50 Irwon-dong,

Gangnam-gu, Seoul, Republic of Korea

e-mail: yhko310@skku.edu
(NHL) [1-3]. The occurrence rates of various subtypes of T- and NK-cell lymphomas in Asia are significantly different from those observed in Western countries, and even among Asian countries. The incidence and distribution of T- and NK-cell lymphomas in several Asian countries is summarized in Fig. 1 and Table 1 [4-15].

The frequencies of T- and NK-cell lymphomas seem to increase from West to East Asia. The occurrence rate of Tand NK-cell lymphomas are relatively low $(<20 \%$ of NHL) mainly in West Asia (Turkey $16.2 \%$, Iraq $19 \%$, and Kuwait $18 \%$ ) and South Asia (Pakistan $11.3 \%$, and India $20.2 \%$ ), but relatively high mainly in East Asia (China $32.5 \%$, Korea $22 \%$, and Japan $24.9 \%$ ) and Southeast Asia (Thailand $25 \%$ ). The proportion of T- and NK-cell lymphomas in Taiwan is very low (13.3\%) compared with that of other East Asian countries. Regarding the subtypes of T- and NK-cell lymphomas, two West (Turkey and Iraq) and one South (Pakistan) Asian countries share similar distribution patterns, presenting $\mathrm{T}$ lymphoblastic lymphoma (T-LBL) as the most common subtype, followed by peripheral T-cell lymphoma (PTCL) or anaplastic largecell lymphoma (ALCL). The frequency of mycosis fungoides/sezary syndrome (MF/SS) is very high in Kuwait. The distribution patterns of T- and NK-cell lymphomas in Thailand, Taiwan, and Korea are similar, whereas adult T-cell leukemia/lymphoma (ATLL) represents a high proportion of $\mathrm{T}$ - and NK-cell lymphomas in Japan. When ATLL is excluded, four countries (Thailand, Taiwan, Korea, and Japan) exhibit very similar patterns of subtype distribution of T- and NK-cell lymphomas. Extranodal NK/ T-cell lymphoma (ENKL) is frequent in China $(48 \%)$ and Korea $(28.7 \%)$, but is less frequent in Japan $(10.4 \%)$, as reported by a recent study performed by an international T-cell project [2]. In China, the frequency of T- or NK-cell lymphoma varies according to geographic region and 


\section{Frequency of T and NK-cell lymphomas in Asia}

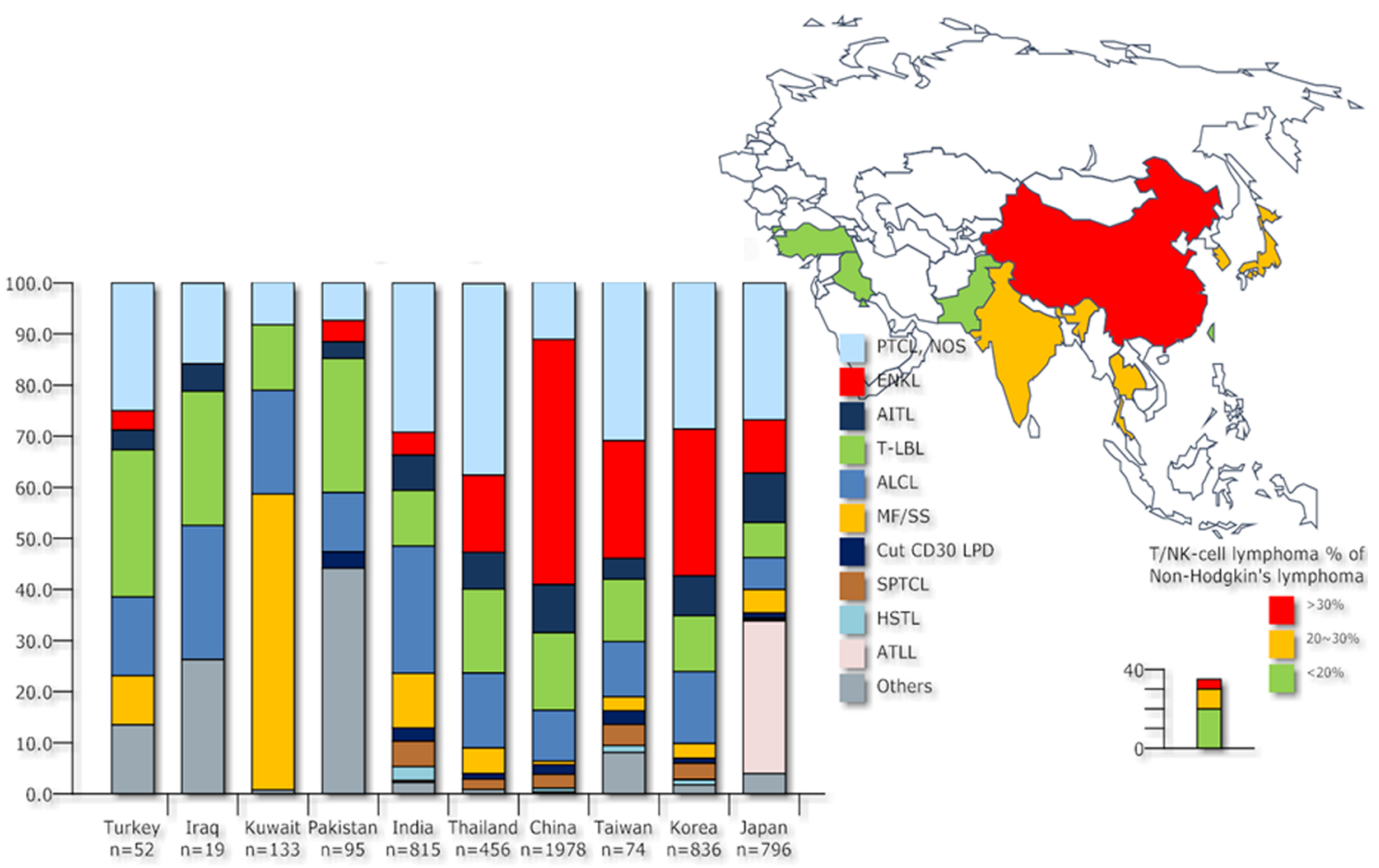

Geographic variations of T or NK-cell lymphomas in China

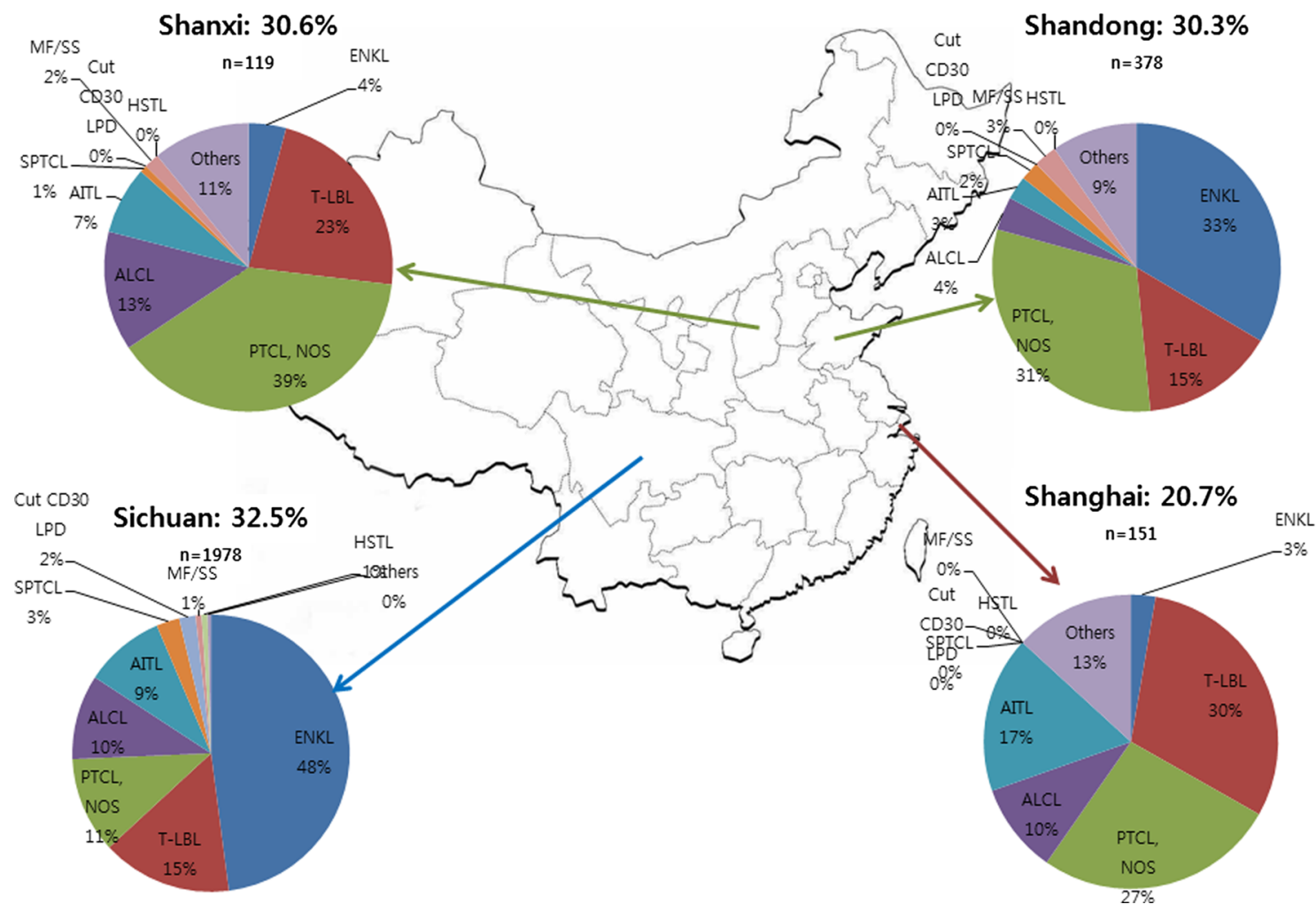

Fig. 1 The incidence and distribution of the T- and NK-cell lymphomas in Asia. a The frequency of T- and NK-cell lymphomas is relatively high in East Asia and Southeast Asia compared to West
Asia and South Asia. b The frequency and subtypes of T- or NK-cell lymphoma in China show regional difference 


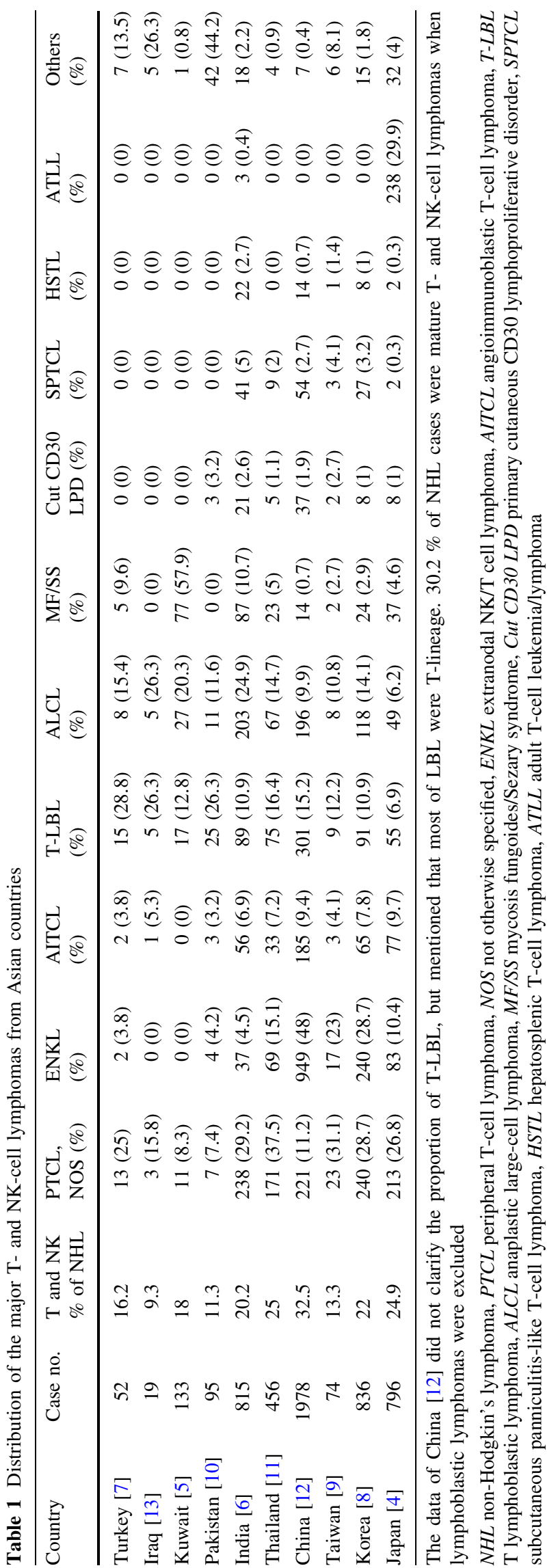

ranges from 20.7 to $32.5 \%$ (Fig. 1). ENKL is the most common subtype of T- or NK-cell lymphoma in Shandong (northern China) and Sichuan (southwestern China), whereas PTCL, NOS, or T-LBL is the most common form in Shanghai (southern China) and Shanxi (northern China) [14, 16]. India shows an intermediate distribution pattern, between West Asian and East Asian countries: the frequency of T- or NK-cell lymphoma is usually higher than in the Western literature, but less than the frequency documented in some Asian countries. The frequency of ENKL $(4.5 \%)$ is similar to that reported in other Indian studies $[10,17]$.

\section{Node-based T-cell lymphomas}

Angioimmunoblastic T-cell lymphoma

Angioimmunoblastic T-cell lymphoma (AITCL) is a major subset of PTCLs, accounting for 16, 28.7, and $17.9 \%$ of mature T-cell lymphoma in North America, Europe, and Asia, respectively [2]. In Asia, proportion of AITCL among all T- and NK-cell lymphomas was $9.7 \%$ in Japan, $9.4 \%$ in China, $7.8 \%$ in Korea, $7.2 \%$ in Thailand, $6.9 \%$ in India, and $4.1 \%$ in Taiwan [4, 8-12]. AITCL is a primarily nodal disease with unique clinical findings. The patients are middle- or old-aged individuals who usually present with systemic lymphadenopathy, hepatosplenomegaly, constitutional symptoms, and skin rashes. The tumor is composed of a polymorphic infiltrate, including neoplastic $\mathrm{T}$ cells, plasma cells, immunoblasts, and small B cells with arborizing highendothelial venules, and a dense meshwork of follicular dendritic cells (Fig. 2). Neoplastic cells express CD3, CD4, CXCR5, CD57, and BCL6, which are markers of normal follicular helper T (TFH) cells, and PD-1, CD10, ICOS-1, and CXCL-13 [18]. Although PD-1 is the most sensitive marker for the detection of TFH cells, the proportion of PD-1-positive T cells among CD3-positive lymphocytes is often much lower, suggesting that many AITCL cases have notoriously low tumor contents. Almost all cases harbor an Epstein-Barr virus (EBV)infected B-cell population, which reflects a defect in the T-cell immune surveillance that eradicates the virus.

Follicular helper $\mathrm{T}$ cells are crucial for the establishment of germinal center reactions and the generation of high-affinity antibodies, memory B cells, and long-lived plasma cells. Overstimulation of TFH cells, linked with a dysregulated humoral immune response, can explain the peculiar clinical findings of AITCL, including B-cell proliferation, marked plasmacytic differentiation, hypergammaglobulinemia, and Coombs-positive hemolytic anemia [19, 20]. Many patients with AITCL show 


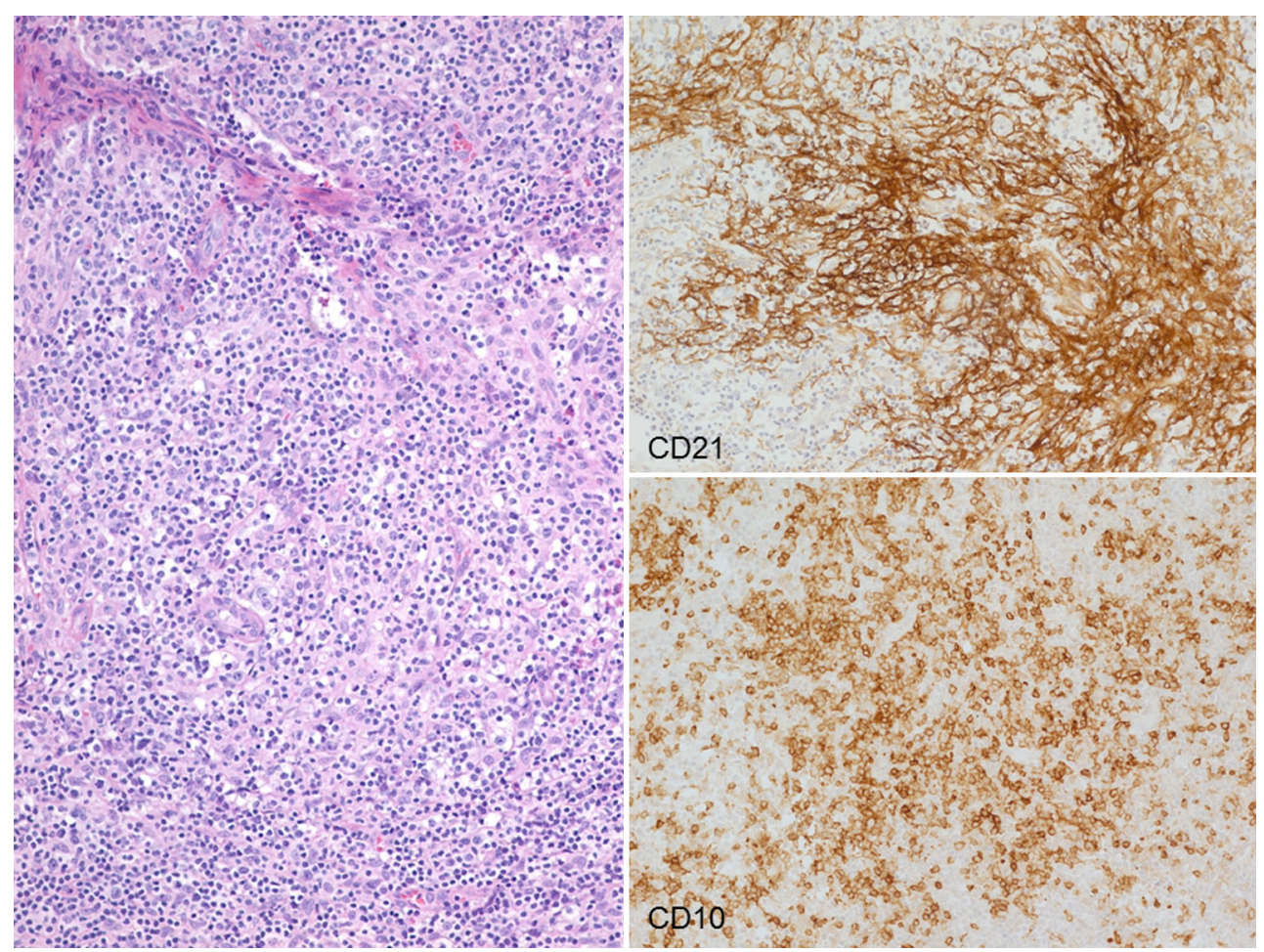

Fig. 2 Angioimmunoblastic T cell lymphoma showing hyperplastic follicular dendritic cell meshwork (CD21). Small tumor cells express follicular helper T-cell markers including CD10

evidence of immunodeficiency, with a reduction of $\mathrm{T}$ cells, an inverted CD4/CD8 ratio, and defective T-cell function in vivo and in vitro [21]. Reports of the development of clonal T-cell proliferation mimicking AITCL in chronic immunosuppressive condition suggest a role of the underlying immune defect in the pathogenesis of AITCL $[22,23]$. These patients usually exhibit an aggressive clinical course and show a dismal outcome with the current therapies [24].

In accordance with pathological findings, the gene expression profile of AITCL shows a specific TFH cell signature and a strong microenvironment imprint [25]. Recently, isocitrate dehydrogenase 2 (IDH2) mutation was identified by Sanger sequencing in about $20 \%$ of AITCL cases [26]. The mutations are not specific to malignant lymphoma; rather, they seem to be specific for AITCL, as no other subtypes of malignant lymphoma had this mutation. TET gene mutation is common in mature T-cell lymphoma, as it was observed in $47 \%$ of AITCL and $37 \%$ of PTCL, NOS, especially with a follicular helper T-cell phenotype [27]. TET2 mutation is frequently accompanied by DNMT3 mutation, which is involved in cytosine methylation. Mutation of epigenetic regulators, including TET2, $D N M T 3$, and $I D H 2$, is involved in the epigenetic control of transcription, and the oncogenic cooperation between epigenetic regulators seems to play a role in the pathogenesis of AITCL.
Peripheral T-cell lymphoma, NOS, follicular variant (PTCL-F)

The follicular variant of T-cell lymphoma (PTCL-F) is described as a variant of PTCL, NOS, in the 2008 WHO Classification of Tumours of Haematopoietic and Lymphoid Tissues [28]. The histological appearance of PTCL-F is variable and consists of atypical clear cells that form intrafollicular aggregates (mimicking follicular lymphoma), small nodular aggregates in a background of progressively transformed germinal centers (mimicking nodular lymphocyte-predominant Hodgkin's lymphoma), or an enlarged perifollicular zone (mimicking nodal marginal zone lymphoma) [28]. The overall architecture is often minimally or partially effaced. PTCL-F displays a TFH phenotype and usually expresses more than three TFH-cell markers, including PD-1, CXCL-13, ICOS-1, CD10, CD4, and BCL-6. Phenotypic overlapping with AITCL has raised the question of a possible relationship between the two lymphoma types [29]. PTCL-F was not grouped with AITCL in the 2008 WHO classification because of its presentation in a low-stage, partial organ involvement, lower frequency of polymorphous reactive background, and lack of hyperplastic high-endothelial venules compared with typical AITCL; however, recent accumulating clinical, morphological, and genetic evidence suggest that PTCL-F may not be a distinct entity; rather, it 
may represent a spectrum of AITCL [30]. Clinically, the coexistence of PTCL-F and AITCL in the same patient has been reported [31]. Some patients who were initially diagnosed with AITCL relapsed with PTCL-F [32]. Morphologically, some cases of PTCL-F can show many morphological features of AITCL, including focal regressed follicles, high-endothelial venule hyperplasia, and focal follicular dendritic cell expansion [30]. Genetically, a novel $\mathrm{t}(5 ; 9)(\mathrm{q} 33 ; \mathrm{q} 22)$ mutation that results in the fusion of ITK-SYK was reported in $21 \%$ of PTCL-F cases. The ITK-SYK fusion is not unique to PTCL-F, as it has been reported in a few cases of PTCL, NOS, and AITCL [30, 33, 34], suggesting that a common genetic alteration is shared among TFH-cell neoplasms.

Anaplastic large-cell lymphomas

\section{ALK-positive ALCL}

ALK-positive ALCL shows a broad morphological spectrum with a variable proportion of hallmark cells and a translocation involving the $A L K$ gene, with expression of the ALK protein and CD30 (Fig. 3) [35]. ALK-positive ALCL accounts for 16, 6.4, and $3.2 \%$ of mature T-cell lymphoma in North America, Europe, and Asia, respectively [2]. It affects mostly the lymph nodes, with extranodal involvement observed in $60 \%$ of cases, most commonly in soft tissue and bone [36, 37]. Primary involvement of the skin and brain is rare, as only a few cases have been reported [30, 38, 39]. The majority of primary cutaneous ALK-positive ALCL cases reported recently had a small-cell component. The ALK protein was expressed in the cytoplasm and nucleus, indicating an underlying NPM-ALK fusion in most cases. Primary cutaneous ALCL is regarded as part of the spectrum of primary cutaneous CD30-positive T-cell lymphoproliferative disorders that are negative for the ALK protein. The histopathological and clinical pictures of the skin-restricted ALK-positive ALCL are indistinguishable from those of primary cutaneous ALCL, raising the necessity of performing ALK staining in all cases of ALCL encountered in the skin [38].

\section{ALK-negative ALCL}

ALK-negative ALCL represents 7.8, 9.4, and $2.6 \%$ of mature T-cell lymphomas in North America, Europe, and Asia, respectively [2]. ALK-negative ALCL is defined as a CD30+ T-cell neoplasm that is not reproducibly distinguishable based on morphological features from ALKpositive ALCL, but lacks the ALK protein, according to the 2008 WHO classification [40]. In conjunction with strong and abundant CD30 expression in almost all cells, other features that favor this diagnosis are the absence of a B-cell program, as demonstrated by the lack of Pax 5 expression (with the exception of cases with PAX5 gene amplification), loss of T-cell markers, expression of EMA, a cytotoxic phenotype, and lack of T-cell receptor (TCR) expression [41, 42]. ALK-negative ALCL presents with lymph-node involvement in $70 \%$ of cases, and extranodal spread is less common compared with ALK-positive ALCL [40]. The patients have an overall survival rate that lies between those of patients with PTCL, NOS and ALKpositive ALCL [36, 41]. Because the distinction between PTCL, NOS, and ALK-negative ALCL is not always clearcut, ALK-negative ALCL was included in the WHO 2008 classification as a provisional entity; however, emerging evidence shows that it is distinct from PTCL, NOS. Gene expression profiling revealed that gene clusters, including TNFRSF8, SNFT, NFATC2, and PERP, distinguish ALKnegative ALCL from PTCL, NOS and AITCL [43]. RTPCR analysis of TNFRSF8, BATF3, and TMOD1 successfully distinguished ALK-negative ALCL from PTCL, NOS [44]. MicroRNA expression profiling identified molecular signatures that differentiated ALK-negative ALCL from other PTCLs [45]. A balanced translocation that disrupted the DUSP22 phosphatase gene on chromosome 6p25.3 and adjoined the $F R A 7 H$ fragile site on chromosome $7 \mathrm{q} 32.3$ was identified in up to $45 \%$ of ALK-negative ALCL cases [46]. Although the role of such a molecular alteration remains to be determined, the signature specificity for ALK-negative ALCL suggests that this lymphoma represents a unique entity that is discernible from other PTCLs.

\section{Primary breast-implant-related ALK-negative ALCL}

Breast-implant-associated ALCL is a rare clinicopathological entity that has been reported in up to 103 cases to date. Most cases had an ALK-negative phenotype, with the exception of a few ALK-positive cases [47, 48]. It arises in association with the fibrous capsule or effusion around the silicone breast implant [47]. Tumor cells are large immunoblast-like cells with conspicuous nucleoli and degrees of nuclear pleomorphism that express CD30 with variable expression of other T-cell markers, including CD3 in $46 \%$, CD4 in $84 \%$, TIA-1 in $63 \%$, granzyme B in $61 \%$, and CD8 in $15 \%$ of cases, as shown in non-implant-associated ALCL [47]. EBV is negative. An extensive mixed lymphocytic infiltrate adjacent to the fibrous implant capsule suggests the potential role of chronic inflammation and genetic instability in the pathogenesis of breast-implantassociated ALK-negative ALCL [49]. These patients have a good prognosis when the tumor presents solely with effusions around the implant [48]; in contrast, patients who present with a distinct mass may have advanced stage or possibly systemic disease and have a poorer prognosis [50]. 


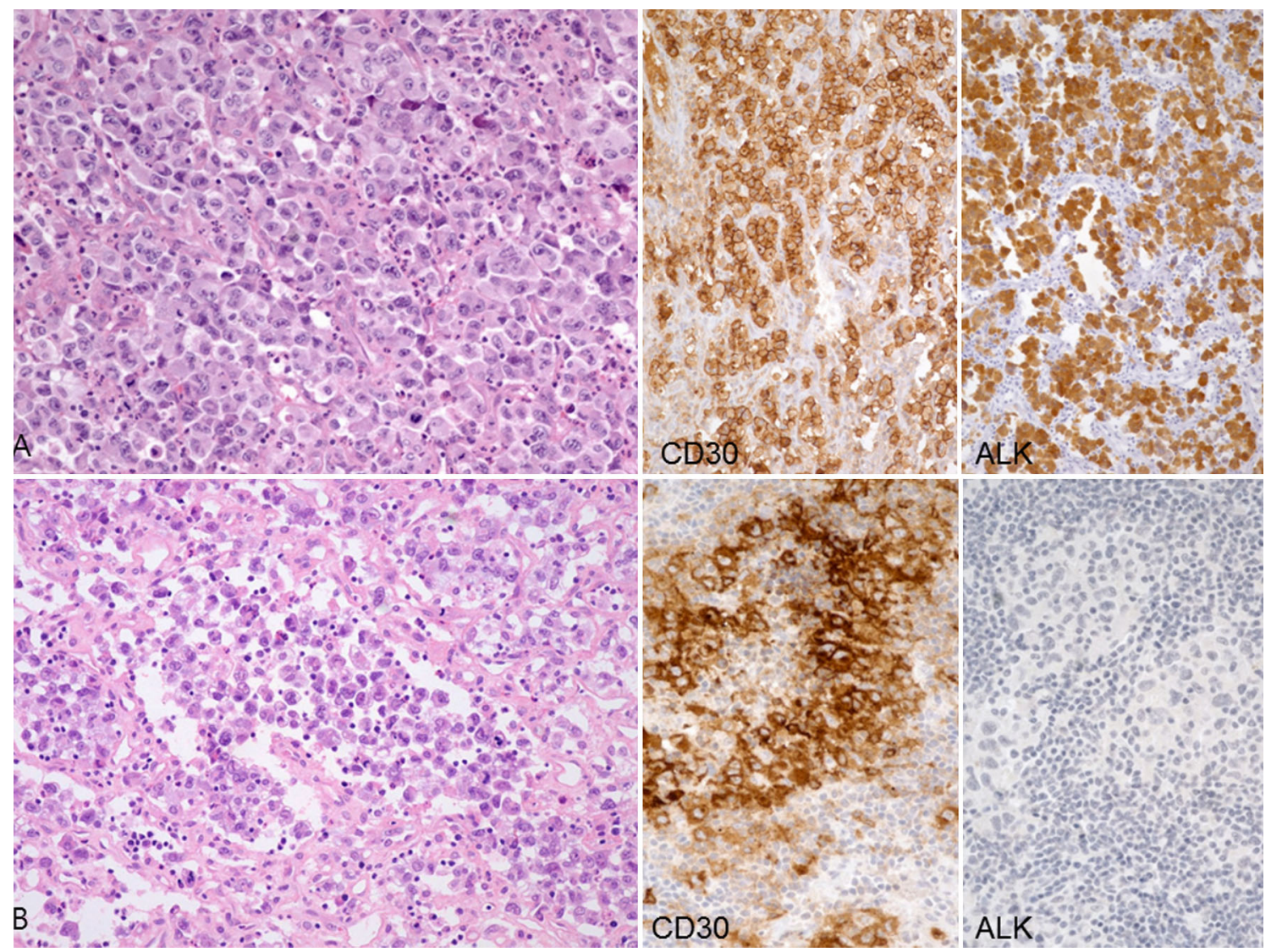

Fig. 3 Anaplastic large-cell lymphomas, ALK-positive shows strong membranous stain for CD30 and nuclear and cytoplasmic stain for ALK protein (upper panel). Anaplastic large-cell lymphoma, ALK-

\section{Gastrointestinal T-cell lymphomas}

In Asian countries, T-lineage mature T-cell lymphomas account for up to $6 \%$ of all gastrointestinal NHL [8]. In the stomach, the frequency of T-cell lymphoma is much lower compared with the intestine and accounts for $<5 \%$ of cases [8]. In the intestine, the proportion of T-cell lineage NHLs is $12 \%$ in Korea [8], $14.7 \%$ in Japan [51], and $32-40.8 \%$ in China $[52,53]$. PTCL, NOS is the most common subtype, followed by enteropathy-associated T-cell lymphoma (EATL) and ENKL $[8,54,55]$.

\section{Enteropathy-associated T-cell lymphoma}

EATL has two forms, type I and type II, with different clinical and pathological features. Type I is characterized by a polymorphous cytological composition, usually an $\alpha \beta$ $\mathrm{T}$ phenotype, but with $\gamma \delta \mathrm{T}$ cells in some cases, and is associated with celiac disease. Type II shows a monomorphic cytology with usually a $\gamma \delta$ T-cell phenotype expressing CD8 and CD56, with some cases of $\alpha \beta$ T cells (Fig. 4). Usually, celiac disease is not associated [56]. In the study performed by the international PTCL project, negative shows anaplastic tumor cells in the lymphatic sinuses. All tumor cells express CD30 but no ALK protein (lower panel)

EATL constituted $5.4 \%$ of all T-cell lymphomas and was most common in Europe $(9.1 \%)$, followed by North America (5.8 \%), and Asia (1.9\%). EATL type I was more common (66 \%) than type II (34\%), and was especially frequent in Europe (79 \%) [57]. In Asia, most EATL was type II, accounting for $100 \%$ of EATL in China, $83 \%$ in Japan, and $87.5 \%$ in Korea [55, 58-60]. In a recent Asian collaborative study, patients with EATL were mostly adult males (median age 58 years, male:female ratio 2.6:1), presenting with abdominal pain $(60 \%)$, intestinal perforation $(40 \%)$, and weight loss $(28 \%)$. None had a history of celiac disease, and the median survival was only 7 months [61]. EATL is a neoplasm of intraepithelial T lymphocytes (IEL) [56]. Among the subset of IEL, type b IEL is far more prevalent in the mucosal epithelium and expresses $\alpha \beta$ TCRs or TCRs with a unique coreceptor, CD8 $\alpha \alpha$, or lacks CD8 and CD4. Although the small and large intestines contain both type a and type b IELs, the ratio between type a and type $b$ IELs differs markedly. The small intestine is rich in CD8 $\alpha \alpha$ IELs, whereas the large intestine contains very few of these cells [62]. The T-cell subset of EATL exhibited a predominance of $\gamma \delta \mathrm{T}$ cells in a study from China. Fourteen $(78 \%)$ cases expressed $\gamma \delta$ 


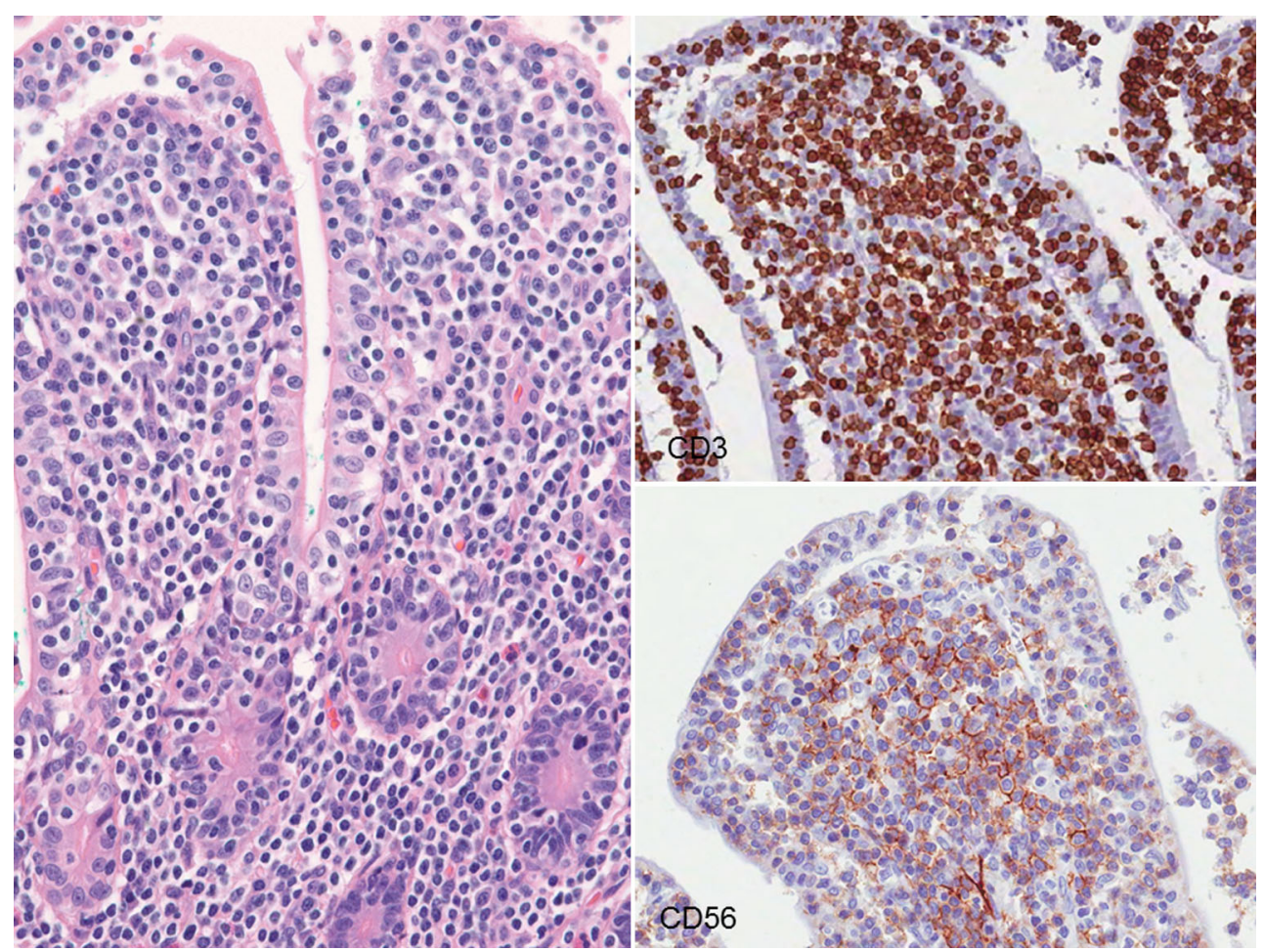

Fig. 4 Enteropathy-associated T cell lymphoma. Small and monotonous tumor cells express CD3 and CD56. Intraepithelial lymphocytosis by tumor cells is highlighted by CD3 stain

TCRs, and only six (33\%) expressed $\alpha \beta$ TCRs (with three cases coexpressing both TCRs) [59]. In an Asian collaborative study, TCR expression was silent or not evaluable in $40 \%$ of cases, whereas the remaining cases exhibited predominant expression of TCR $\alpha \beta$ over TCR $\gamma \delta$ (1.6:1). The immunophenotype was CD8+/CD56+ (88 \%) cytotoxic $\mathrm{T}$ cell and there was frequent aberrant expression of CD20 (24\%). In keeping with the normal ratio of IEL subsets, CD8+ cases showed predominant CD8 $\alpha \alpha$ homodimer expression (77\%), regardless of TCR lineage [61].

Indolent T-cell and NK-cell lymphoproliferative diseases

Indolent T- or NK-cell proliferative diseases, which may be mistaken for aggressive T-cell or NK-cell lymphoma, have been described in the GI tract [63, 64]. Lymphomatoid gastropathy or NK-cell enteropathy is a nonprogressive NK-cell proliferative lesion of unknown etiology that often regresses spontaneously, even when left untreated. The histological features of these cases include superficial, but confluent, infiltration of medium or large cells, with a moderate-to-abundant clear cytoplasm and a variable proportion of cells with peculiar eosinophilic granules in the cytoplasm [64]. EBER in situ hybridization is always negative, which is an important differential feature from
ENKL. The lineage of infiltrated cells is assumed to be NK cells, because they have a $\mathrm{CD} 2+/-$ and cytoplasmic $\mathrm{CD} 3+, \mathrm{CD} 4-, \mathrm{CD} 7+, \mathrm{CD} 8-, \mathrm{CD} 56+$, TIA1+, granzyme $\mathrm{B}+$ phenotype, and the TCR gene rearrangement is polyclonal [64]. Similar indolent proliferations of T cells were reported involving the oral cavity, esophagus, stomach, small intestine, and colon. The infiltrates were nondestructive and composed of small, mature-appearing lymphoid cells that were clonal, CD8-positive and, less commonly, CD4-positive or CD4/CD8-negative T cells. The clinical course is indolent, and none of the patients showed progression of tumor size or the extent of involvement [65].

\section{Primary cutaneous T-cell lymphomas}

Primary cutaneous lymphomas are defined as cutaneous lymphomas (CTLs) that present in the skin with no evidence of extracutaneous disease at the time of diagnosis. The estimated annual incidence of this condition is $1: 100,000$ in the USA [66]. The proportion of the T-cell subtype is higher in Korea $(81.6-84.3 \%)$ [67, 68] and Japan $(80-86.8 \%)[69,70]$ than it is in the USA $(71.3 \%)$ and Europe $(77.6 \%)$ [ 71,72$]$. The most common subtypes in Western countries are MF/SS, CD30+ lymphoproliferative disorder of the skin (CD30+ LPD), and PTCL in 
Europe, and MF/SS, PTCL, and CD30+ LPD in the USA, in decreasing order of frequency $[71,72]$.

In Asia, the major subtype is MF/SS, followed by CD30+ LPD in Korea and Japan [67-70]. The third most common subtype was PTCL or ATLL in Japan $[69,70]$. A recent Korean nationwide study revealed that the most common subtypes in that country are MF/SS, PTCL, CD30+ LPD, and ENKL, in decreasing order of frequency (unpublished data). The frequency of PTCL of primary cutaneous T-cell lymphomas (PCTLs) is variable, ranging 9.2-12.3\% in Korea and from 4.3 to $16 \%$ in Japan [6770]. PTCL encompasses PTCL, NOS, primary cutaneous $\gamma \delta$ T-cell lymphoma $(\gamma \delta \mathrm{TCL})$, primary cutaneous CD8+ aggressive epidermotropic cytotoxic T-cell lymphoma (CD8TCL), and primary cutaneous CD4+ small/medium T-cell lymphoma (CD4TCL). The incidence of PTCL subtypes ( $\gamma \delta \mathrm{TCL}, \mathrm{CD} 8 \mathrm{TCL}$, and CD4TCL) has not been clarified in Asia, because these subtypes were included in the WHO 2008 classification as provisional entities and are difficult to differentiate from other CTLs. In one Korean study, the proportion of PTCL was $12.3 \%$ of all PCTLs and consisted of CD4TCL (50\%), PTCL, NOS (30\%), and $\gamma \delta$ TCL (20\%) [68].

\section{Primary cutaneous $\gamma \delta$ T-cell lymphoma}

Primary cutaneous $\gamma \delta$ T-cell lymphoma $(\gamma \delta \mathrm{TCL})$ is a neoplasm of activated $\gamma \delta \mathrm{T}$ cells with a cytotoxic phenotype [73]. Patients present with multiple nodules on the trunk and limbs or generalized ulcerated plaques. Its histological findings are variable and include upper dermal infiltration with marked epidermotropism with ulceration of the epidermis, diffuse dermal infiltration, or involvement of the subcutis with a subcutaneous panniculitis-like pattern [74]. Most patients experience an aggressive clinical course with extranodal and nodal dissemination [74, 75]. The identification of primary cutaneous $\gamma \delta \mathrm{TCL}$ was difficult until the TCR $\gamma$ and TCR $\delta$ antibodies for paraffinsection immunohistochemistry became available commercially. In the two most recent studies, the immunophenotype of $\gamma \delta$ TCL was CD4-/CD8- in six cases and CD4-/ $\mathrm{CD} 8+$ in five cases. TCR $\gamma$ or TCR $\delta$ was detected in all cases, with simultaneous expression of $\beta \mathrm{F} 1$ in one case $[74$, 75]. All cases express cytotoxic granules that include granzyme B, perforin, and TIA-1. TCR $\gamma$ expression is not exclusive to $\gamma \delta \mathrm{TCL}$, as it can be found in other CTLs, including lymphomatoid papulosis or mycosis fungoides [74]. The diagnosis should be made on the proper clinical and pathologic context. The genetic and cytogenetic abnormalities of $\gamma \delta \mathrm{TCL}$ have not been investigated well. One study demonstrated the presence of several chromosomal translocations involving breakpoints at chromosomes $9 \mathrm{p} 21,14 \mathrm{q} 11.2,14 \mathrm{q} 32.1$, or $16 \mathrm{q} 23.1$, suggesting the involvement of $W W O X$, the $T C L$ gene cluster, and $B C L 11 B$ [76].

Primary cutaneous CD8+ aggressive epidermotropic cytotoxic T-cell lymphoma

Primary cutaneous CD8+ aggressive epidermotropic cytotoxic T-cell lymphoma (CD8TCL) is an aggressive CTL that is derived from epidermotropic CD8+ cytotoxic $\alpha \beta \mathrm{T}$ cells. The immunophenotype of this tumor is always CD4-/ $\mathrm{CD} 8+$. Because the CD4-/CD8+ phenotype is not exclusive to CD8TCL, other CD8+ TCLs, including CD8+ mycosis fungoides, lymphomatoid papulosis type $\mathrm{D}$, and indolent $\mathrm{CD} 8+$ lymphoproliferation of the ear or acral sites, should be differentiated based on pathological and clinical findings [77-79]. The prognosis of this disease is usually poor, which can be attributed to highly aggressive clinical lesions that usually result in a rapid metastatic spread, a lower response rate to chemotherapy, and a higher incidence of relapse [77]. Conversely, some cases with a favorable outcome have been reported [78, 79], suggesting that CD8TCL has a heterogeneous clinical behavior. In this regard, it was suggested that patients presenting with a single or few nonaggressive lesions and who respond well to conventional CD4+ CTL treatment (localized radiotherapy and PUVA) should not be considered as having CD8TCL, and that two characteristic clinical features (disseminated ulcerated papules, plaques, nodules, and/or tumors without longstanding precursor lesions and an aggressive behavior that leads to rapid progression of the lesions over the skin surface and usually to extracutaneous sites) must be present to define this entity accurately [77].

\section{Primary cutaneous CD4+ small/medium T-cell lymphoma}

Primary cutaneous CD4+ small/medium T-cell lymphoma (CD4TCL) is associated with an excellent prognosis and presents characteristically with a solitary plaque or tumor that is generally localized on the face or the upper trunk and rarely presents with multiple papules, plaques, or tumors [80, 81]. Histologically, CD4TCL shows nodularto-diffuse infiltrates with a predominance of $\mathrm{CD} 3+$, CD4+, CD8-, CD30- small-to-medium-sized pleomorphic $\mathrm{T}$ cells and a small proportion $(<30 \%)$ of large CD4 pleomorphic $\mathrm{T}$ cells. In most cases, there is a considerable admixture with small reactive $\mathrm{CD} 8+\mathrm{T}$ cells and $\mathrm{CD} 20+\mathrm{B}$ cells [82]. Large atypical CD4+ T cells express TFH-cell markers (PD-1, BCL-6, and CXCL-13) [83]. Although PD1 is the most useful marker for the recognition of CD4TCL, pseudo T-cell lymphoma also expressed PD-1 [84]. Therefore, the distinction between these two groups is very difficult. T-cell monoclonality is not helpful for this 
discrimination, because not all CD4TCL cases are clonal and T-cell clonality has been demonstrated even in pseudo T-cell lymphomas with the advent of new and more sensitive techniques. The distinction from cutaneous B-cell lymphomas, such as cutaneous marginal zone B-cell lymphoma, is sometimes problematic because of the predominance of B-cell infiltrates.

\section{Epstein-Barr virus (EBV)-associated T- or NK-cell lymphoproliferative disorders}

EBV is an important factor that is associated with a higher incidence of T- or NK-cell lymphoma in East Asia compared with Europe and the USA. ENKL was the most common subtype in a Korean study, accounting for 89 of 107 EBV-positive T- or NK-type NHL cases ( $83 \%$ ), followed by aggressive NK-cell leukemia (8.4\%) [85].

\section{Extranodal NK/T-cell lymphoma}

ENKL, nasal type, is either of NK or T-cell lineage. The percentage of ENKL, nasal type, of T-cell origin, according to PCR-based research, ranges $0-38 \%$ [86]. One phenotype study reported that ENKL, nasal type, was of NK origin $(70 \%)$, TCR $\gamma \delta+(5 \%)$, TCR $\alpha \beta+(3 \%)$, TCR $\alpha \beta /$ $\gamma \delta+(1 \%)$, and indeterminate (21\%) [87]. Deletion of chromosome 6q (6q21-6q25) is the most frequent genomic aberration, and the FOXO3 and PRDMI tumor-suppressor genes have been identified in the 6q21-q25 region [88]. Studies have also demonstrated genetic aberrations related to important functions, including apoptosis $(F A S)$, cell cycle (TP73, CDKN2A, CDKN2B, and CDKN1A), signaling pathways (KIT, $C T N N B 1$, and $J A K 3$ ), tumor-suppressor genes (TP53, PRDM1, AIM1, FOXO3, and HACE1), and oncogenes (RAS/KRAS/HRAS and MYC) [89]. Although the molecular profile of ENKL, nasal type, differs from that of other PTCLs, a subset of extranodal lymphomas derived from $\gamma \delta \mathrm{T}$ cells has a molecular signature that is very similar to that of ENKL, nasal type [90] (Fig. 5).

\section{EBV-positive T/NK-cell LPD of childhood}

EBV-positive T-cell LPD of childhood comprises a broad spectrum of EBV-associated LPDs with different clinical presentations, including systemic T-cell LPD of childhood, systemic chronic active EBV infection (CAEBV), hydrovacciniforme (HV)-type T-cell LPD, and mosquito-bite hypersensitivity. It is a very rare disease, and only sporadic cases or small series of this entity have been reported. Patients with CAEBV show a high viral load in the peripheral blood or in tissues, as well as chronic illness including fever, organomegaly, and skin lesions of unknown etiology. Clonal expansion and transformation of

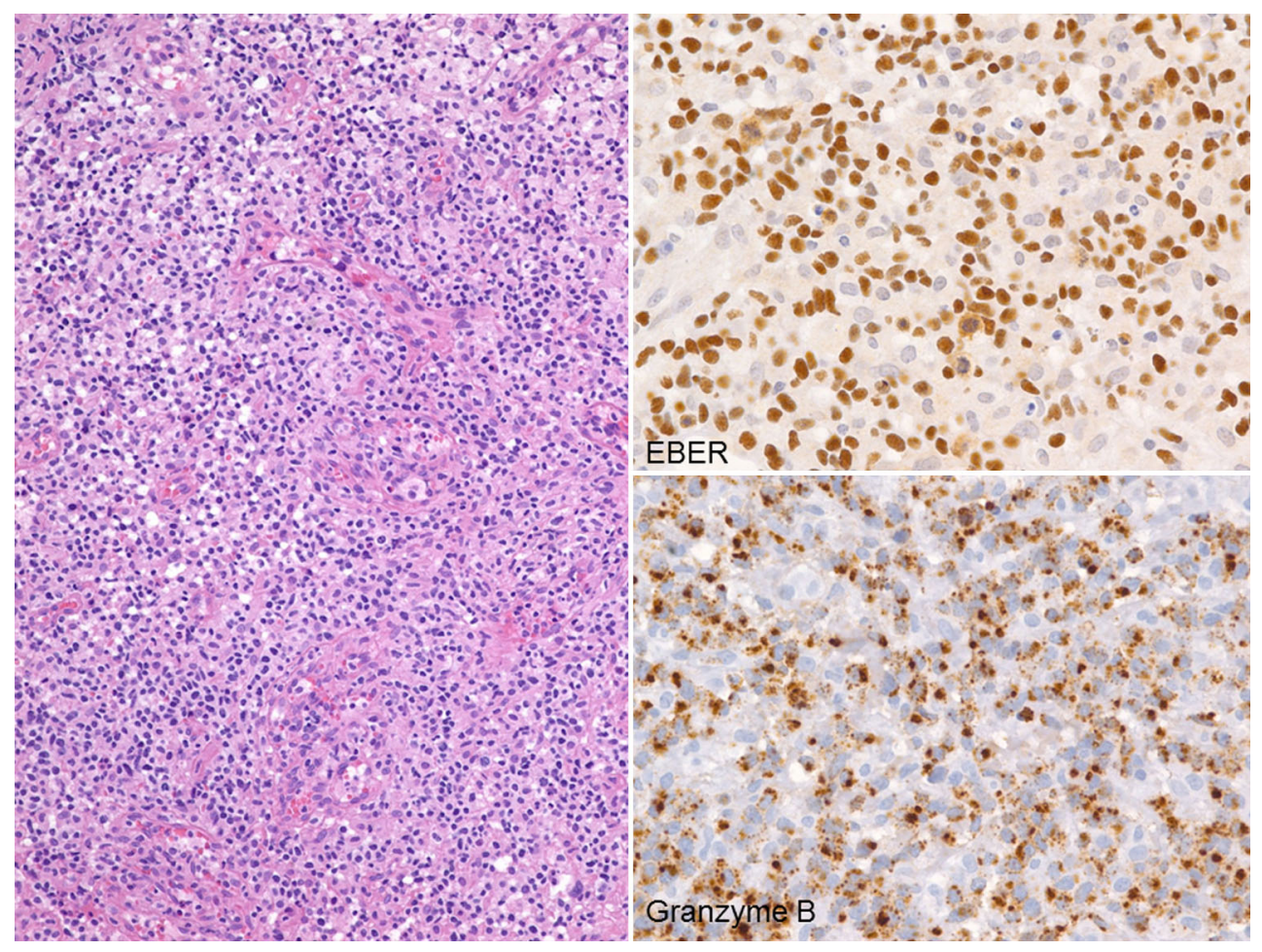

Fig. 5 Extranodal NK/T cell lymphoma, nasal type. EBV is detected in most tumor cells by EBER in situ hybridization. Cytotoxic granules including granzyme $\mathrm{B}$ are expressed in the cytoplasm of tumor cells 
EBV-infected $\mathrm{T}$ and NK cells are the main pathogenic factors. The clinical course of this disease depends on the balance between EBV-related factors and host immune function, and can be smoldering, progressive, or aggressive. The EBV-infected $\mathrm{T}$ or NK cells in CAEBV frequently lack histological evidence of malignancy, and range from polyclonal, to oligoclonal, to monoclonal. Monoclonal cases of CAEBV are termed systemic T-cell LPD of childhood in the WHO 2008 classification [91]. Both HV and mosquito-bite allergy are cutaneous forms of CAEBV, but can progress to systemic involvement and a more fulminant disease. The spectrum of HV to HV-like T-cell lymphoma is somewhat of a continuum, but clinical, histological, and molecular features are all useful for its classification [30].

Acknowledgments This study was supported by a Samsung Biomedical Research Institute Grant (No. SP1B20412).

Conflict of interest The authors have no conflict of interest to disclose.

\section{References}

1. Anderson JR, Armitage JO, Weisenburger DD. Epidemiology of the non-Hodgkin's lymphomas: distributions of the major subtypes differ by geographic locations. Non-Hodgkin's Lymphoma Classification Project. Ann Oncol. 1998;9:717-20.

2. Vose J, Armitage J, Weisenburger D. International peripheral T-cell and natural killer/T-cell lymphoma study: pathology findings and clinical outcomes. J Clin Oncol. 2008;26:4124-30.

3. Nakamura S, Koshikawa T, Koike K, Kitoh K, Suzuki H, Oyama $\mathrm{A}$, et al. Phenotypic analysis of peripheral $\mathrm{T}$ cell lymphoma among the Japanese. Acta Pathol Jpn. 1993;43:396-412.

4. The world health organization classification of malignant lymphomas in japan: incidence of recently recognized entities. Lymphoma Study Group of Japanese Pathologists. Pathol Int. 2000;50:696-702.

5. Ameen R, Sajnani KP, Albassami A, Refaat S. Frequencies of non-Hodgkin's lymphoma subtypes in Kuwait: comparisons between different ethnic groups. Ann Hematol. 2010;89:179-84.

6. Arora N, Manipadam MT, Nair S. Frequency and distribution of lymphoma types in a tertiary care hospital in South India: analysis of 5115 cases using the World Health Organization 2008 classification and comparison with world literature. Leuk Lymphoma. 2013;54:1004-11.

7. Isikdogan A, Ayyildiz O, Buyukcelik A, Arslan A, Tiftik N, Buyukbayram H, et al. Non-Hodgkin's lymphoma in southeast Turkey: clinicopathologic features of 490 cases. Ann Hematol. 2004;83:265-9.

8. Kim JM, Ko YH, Lee SS, Huh J, Kang CS, Kim CW, et al. WHO classification of malignant lymphomas in Korea: report of the third nationwide study. Korean J Pathol AID. 2011;45:254-60. doi:10.4132/KoreanJPathol.45.3.254.

9. Lee MY, Tan TD, Feng AC, Liu MC. Clinicopathological analysis of malignant lymphoma in Taiwan, defined according to the World Health Organization classification. Haematologica. 2005;90:1703-5.

10. Naresh KN, Advani S, Adde M, Aziz Z, Banavali S, Bhatia K, et al. Report of an International Network of Cancer Treatment and Research workshop on non-Hodgkin's lymphoma in developing countries. Blood Cells Mol Dis. 2004;33:330-7.

11. Sukpanichnant S. Analysis of 1983 cases of malignant lymphoma in Thailand according to the World Health Organization classification. Hum Pathol. 2004;35:224-30.

12. Yang QP, Zhang WY, Yu JB, Zhao S, Xu H, Wang WY, et al. Subtype distribution of lymphomas in Southwest China: analysis of 6,382 cases using WHO classification in a single institution. Diagn Pathol. 2011;6:77.

13. Yaqo RT, Hughson MD, Sulayvani FK, Al-Allawi NA. Malignant lymphoma in northern Iraq: a retrospective analysis of 270 cases according to the World Health Organization classification. Indian J Cancer. 2011;48:446-51.

14. Gross SA, Zhu X, Bao L, Ryder J, Le A, Chen Y, et al. A prospective study of 728 cases of non-Hodgkin lymphoma from a single laboratory in Shanghai, China. Int $\mathrm{J}$ Hematol. 2008;88:165-73.

15. Liu J, Song B, Fan T, Huang C, Xie C, Li J, et al. Pathological and clinical characteristics of 1,248 non-Hodgkin's lymphomas from a regional cancer hospital in Shandong, China. Asian Pac J Cancer Prev. 2011;12:3055-61.

16. Wang J, Young L, Win W, Taylor CR. Distribution and ZAP-70 expression of WHO lymphoma categories in Shanxi, China: a review of 447 cases using a tissue microarray technique. Appl Immunohistochem Mol Morphol. 2005;13:323-32.

17. Sahni CS, Desai SB. Distribution and clinicopathologic characteristics of non-Hodgkin's lymphoma in India: a study of 935 cases using WHO classification of lymphoid neoplasms (2000). Leuk Lymphoma. 2007;48:122-33.

18. Krenacs L, Schaerli P, Kis G, Bagdi E. Phenotype of neoplastic cells in angioimmunoblastic T-cell lymphoma is consistent with activated follicular B helper T cells. Blood. 2006;108:1110-1.

19. Baumjohann D, Preite S, Reboldi A, Ronchi F, Ansel KM, Lanzavecchia A, et al. Persistent antigen and germinal center B cells sustain $\mathrm{T}$ follicular helper cell responses and phenotype. Immunity. 2013;38:596-605.

20. Fazilleau N, Mark L, McHeyzer-Williams LJ, McHeyzer-Williams MG. Follicular helper $\mathrm{T}$ cells: lineage and location. Immunity. 2009;30:324-35.

21. Pizzolo G, Chilosi M, Fiore-Donati L, Perona G. Imbalance of peripheral blood and lymph node $\mathrm{T}$ cell subpopulations in angioimmunoblastic lymphadenopathy. Report of three cases. Haematologica. 1983;68:591-9.

22. Steciuk MR, Massengill S, Banks PM. In immunocompromised patients, Epstein-Barr virus lymphadenitis can mimic angioimmunoblastic T-cell lymphoma morphologically, immunophenotypically, and genetically: a case report and review of the literature. Hum Pathol. 2012;43:127-33.

23. Hatanaka K, Nakamura N, Kojima M, Ando K, Irie S, Bunno M, et al. Methotrexate-associated lymphoproliferative disorders mimicking angioimmunoblastic T-cell lymphoma. Pathol Res Pract. 2010;206:9-13.

24. Federico M, Rudiger T, Bellei M, Nathwani BN, Luminari S, Coiffier B, et al. Clinicopathologic characteristics of angioimmunoblastic T-cell lymphoma: analysis of the international peripheral T-cell lymphoma project. J Clin Oncol. 2013;31:240-6.

25. de Leval L, Rickman DS, Thielen C, Reynies A, Huang YL, Delsol G, et al. The gene expression profile of nodal peripheral T-cell lymphoma demonstrates a molecular link between angioimmunoblastic T-cell lymphoma (AITL) and follicular helper T (TFH) cells. Blood. 2007;109:4952-63.

26. Cairns RA, Iqbal J, Lemonnier F, Kucuk C, de Leval L, Jais JP, et al. IDH2 mutations are frequent in angioimmunoblastic T-cell lymphoma. Blood. 2012;119:1901-3.

27. Lemonnier F, Couronne L, Parrens M, Jais JP, Travert M, Lamant $\mathrm{L}$, et al. Recurrent TET2 mutations in peripheral T-cell 
lymphomas correlate with TFH-like features and adverse clinical parameters. Blood. 2012;120:1466-9.

28. Pileri SA, Weisenburger DD, Sng I, Jaffe ES, Ralfkiaer E, Nakamura $\mathrm{S}$, et al. Peripheral T-cell lymphoma, not otherwise specified. In: Swerdlow SH, Campo E, Harris NL, Jaffe ES, Pileri SA, Stein H, et al., editors. WHO classification of tumours of haematopoietic and lymphoid tissues. Lyon: WHO; 2008. p. $306-8$.

29. Rodriguez-Pinilla SM, Atienza L, Murillo C, Perez-Rodriguez A, Montes-Moreno S, Roncador G, et al. Peripheral T-cell lymphoma with follicular T-cell markers. Am J Surg Pathol. 2008;32:1787-99.

30. Attygalle AD, Cabecadas J, Gaulard P, Jaffe ES, de Jong D, Ko YH, et al. Peripheral T-cell and NK-cell lymphomas and their mimics; taking a step forward-report on the lymphoma workshop of the XVIth meeting of the European Association for Haematopathology and the Society for Hematopathology. Histopathology. 2014;64:171-99.

31. Zhan HQ, Li XQ, Zhu XZ, Lu HF, Zhou XY, Chen Y. Expression of follicular helper $\mathrm{T}$ cell markers in nodal peripheral $\mathrm{T}$ cell lymphomas: a tissue microarray analysis of 162 cases. J Clin Pathol. 2011;64:319-24.

32. Huang Y, Moreau A, Dupuis J, Streubel B, Petit B, Le Gouill S, et al. Peripheral T-cell lymphomas with a follicular growth pattern are derived from follicular helper T cells (TFH) and may show overlapping features with angioimmunoblastic T-cell lymphomas. Am J Surg Pathol. 2009;33:682-90.

33. Streubel B, Vinatzer U, Willheim M, Raderer M, Chott A. Novel $\mathrm{t}(5 ; 9)(\mathrm{q} 33 ; \mathrm{q} 22)$ fuses ITK to SYK in unspecified peripheral T-cell lymphoma. Leukemia. 2006;20:313-8.

34. Attygalle AD, Feldman AL, Dogan A. ITK/SYK translocation in angioimmunoblastic T-cell lymphoma. Am J Surg Pathol. 2013;37:1456-7.

35. Delsol G, Falini B, Muller-Hermelink HK, Campo E. Anaplastic large cell lymphoma (ALCL), ALK-positive. In: Swerdlow SH, Campo E, Harris NL, Jaffe ES, Pileri SA, Stein H, et al., editors. WHO classification of tumours of haematopoietic and lymphoid tissues. Lyon: WHO; 2008. p. 312-6.

36. Savage KJ, Harris NL, Vose JM, Ullrich F, Jaffe ES, Connors JM, et al. ALK-anaplastic large-cell lymphoma is clinically and immunophenotypically different from both ALK+ ALCL and peripheral T-cell lymphoma, not otherwise specified: report from the International Peripheral T-Cell Lymphoma Project. Blood. 2008;111:5496-504.

37. Ferreri AJ, Govi S, Pileri SA, Savage KJ. Anaplastic large cell lymphoma. ALK-positive. Crit Rev Oncol Hematol. 2012;83:293-302.

38. Oschlies I, Lisfeld J, Lamant L, Nakazawa A, d'Amore ES, Hansson U, et al. ALK-positive anaplastic large cell lymphoma limited to the skin: clinical, histopathological and molecular analysis of 6 pediatric cases. A report from the ALCL99 study. Haematologica. 2013;98:50-6.

39. Williams D, Mori T, Reiter A, Woessman W, Rosolen A, Wrobel $\mathrm{G}$, et al. Central nervous system involvement in anaplastic large cell lymphoma in childhood: results from a multicentre European and Japanese study. Pediatr Blood Cancer. 2013;60:E118-21.

40. Mason DY, Harris NL, Delsol G, Stein H, Campo E, Kinney MC, et al. Anaplastic large cell lymphoma, ALK-negative. In: Swerdlow SH, Campo E, Harris NL, Jaffe ES, Pileri S, Stein H, et al., editors. WHO classification of tumours of haematopoietic and lymphoid tissues. Lyon: WHO; 2008. p. 317-9.

41. Ferreri AJ, Govi S, Pileri SA, Savage KJ. Anaplastic large cell lymphoma. ALK-negative. Crit Rev Oncol Hematol. 2013;85:206-15.

42. Feldman AL, Law ME, Inwards DJ, Dogan A, McClure RF, Macon WR. PAX5-positive T-cell anaplastic large cell lymphomas associated with extra copies of the PAX5 gene locus. Mod Pathol. 2010;23:593-602.

43. Piva R, Agnelli L, Pellegrino E, Todoerti K, Grosso V, Tamagno $\mathrm{I}$, et al. Gene expression profiling uncovers molecular classifiers for the recognition of anaplastic large-cell lymphoma within peripheral T-cell neoplasms. J Clin Oncol. 2010;28:1583-90.

44. Agnelli L, Mereu E, Pellegrino E, Limongi T, Kwee I, Bergaggio $\mathrm{E}$, et al. Identification of a 3-gene model as a powerful diagnostic tool for the recognition of ALK-negative anaplastic large-cell lymphoma. Blood. 2012;120:1274-81.

45. Liu C, Iqbal J, Teruya-Feldstein J, Shen Y, Dabrowska MJ, Dybkaer K, et al. MicroRNA expression profiling identifies molecular signatures associated with anaplastic large cell lymphoma. Blood. 2013;122:2083-92.

46. Feldman AL, Dogan A, Smith DI, Law ME, Ansell SM, Johnson $\mathrm{SH}$, et al. Discovery of recurrent $\mathrm{t}(6 ; 7)(\mathrm{p} 25.3 ; \mathrm{q} 32.3)$ translocations in ALK-negative anaplastic large cell lymphomas by massively parallel genomic sequencing. Blood. 2011;117:915-9.

47. Taylor CR, Siddiqi IN, Brody GS. Anaplastic large cell lymphoma occurring in association with breast implants: review of pathologic and immunohistochemical features in 103 cases. Appl Immunohistochem Mol Morphol. 2013;21:13-20.

48. Story SK, Schowalter MK, Geskin LJ. Breast implant-associated ALCL: a unique entity in the spectrum of CD30+ lymphoproliferative disorders. Oncologist. 2013;18:301-7.

49. George EV, Pharm J, Houston C, Al-Quran S, Brian G, Dong H, et al. Breast implant-associated ALK-negative anaplastic large cell lymphoma: a case report and discussion of possible pathogenesis. Int J Clin Exp Pathol. 2013;6:1631-42.

50. Aladily TN, Medeiros LJ, Amin MB, Haideri N, Ye D, Azevedo SJ, et al. Anaplastic large cell lymphoma associated with breast implants: a report of 13 cases. Am J Surg Pathol. 2012;36:1000-8.

51. Kohno S, Ohshima K, Yoneda S, Kodama T, Shirakusa T, Kikuchi M. Clinicopathological analysis of 143 primary malignant lymphomas in the small and large intestines based on the new WHO classification. Histopathology. 2003;43:135-43.

52. Yang D, Bae C, Xio Y, Chen J. Clinicopathological analysis of primary intestinal non-Hodgkin's lymphoma: a report of 32 cases. Zhonghua Bing Li Xue Za Zhi. 2004;33:445-8.

53. Gou HF, Zang J, Jiang M, Yang Y, Cao D, Chen XC. Clinical prognostic analysis of 116 patients with primary intestinal nonHodgkin lymphoma. Med Oncol. 2012;29:227-34.

54. Kim SJ, Choi CW, Mun YC, Oh SY, Kang HJ, Lee SI, et al. Multicenter retrospective analysis of 581 patients with primary intestinal non-hodgkin lymphoma from the Consortium for Improving Survival of Lymphoma (CISL). BMC Cancer. 2011;11:321.

55. Sun J, Lu Z, Yang D, Chen J. Primary intestinal T-cell and NKcell lymphomas: a clinicopathological and molecular study from China focused on type II enteropathy-associated T-cell lymphoma and primary intestinal NK-cell lymphoma. Mod Pathol. 2011;24:983-92.

56. Isaacson PG, Chott A, Ott G, Stein H. Enteropathy-associated T-cell lymphoma. In: Swerdlow SH, Campo E, Harris NL, Jaffe ES, Pileri S, Stein $\mathrm{H}$, et al., editors. WHO classification of tumours of haematopoietic and lymphoid tissues. Lyon: WHO; 2008. p. 289-91.

57. Delabie J, Holte H, Vose JM, Ullrich F, Jaffe ES, Savage KJ, et al. Enteropathy-associated T-cell lymphoma: clinical and histological findings from the international peripheral T-cell lymphoma project. Blood. 2011;118:148-55.

58. Ko YH, Karnan S, Kim KM, Park CK, Kang ES, Kim YH, et al. Enteropathy-associated T-cell lymphoma-a clinicopathologic and array comparative genomic hybridization study. Hum Pathol. 2010;41:1231-7. 
59. Chan JK, Chan AC, Cheuk W, Wan SK, Lee WK, Lui YH, et al. Type II enteropathy-associated T-cell lymphoma: a distinct aggressive lymphoma with frequent gammadelta $\mathrm{T}$-cell receptor expression. Am J Surg Pathol. 2011;35:1557-69.

60. Takeshita M, Nakamura S, Kikuma K, Nakayama Y, Nimura S, Yao T, et al. Pathological and immunohistological findings and genetic aberrations of intestinal enteropathy-associated $\mathrm{T}$ cell lymphoma in Japan. Histopathology. 2011;58:395-407.

61. Tan SY, Chuang SS, Tang T, Tan L, Ko YH, Chuah KL, et al. Type II EATL (epitheliotropic intestinal T-cell lymphoma): a neoplasm of intra-epithelial T-cells with predominant CD8alphaalpha phenotype. Leukemia. 2013;27:1688-96.

62. Kunisawa J, Takahashi I, Kiyono H. Intraepithelial lymphocytes: their shared and divergent immunological behaviors in the small and large intestine. Immunol Rev. 2007;215:136-53.

63. Mansoor A, Pittaluga S, Beck PL, Wilson WH, Ferry JA, Jaffe ES. NK-cell enteropathy: a benign NK-cell lymphoproliferative disease mimicking intestinal lymphoma: clinicopathologic features and follow-up in a unique case series. Blood. 2011;117:1447-52.

64. Takeuchi K, Yokoyama M, Ishizawa S, Terui Y, Nomura K, Marutsuka K, et al. Lymphomatoid gastropathy: a distinct clinicopathologic entity of self-limited pseudomalignant NK-cell proliferation. Blood. 2010;116:5631-7.

65. Perry AM, Warnke RA, Hu Q, Gaulard P, Copie-Bergman C, Alkan S, et al. Indolent T-cell lymphoproliferative disease of the gastrointestinal tract. Blood. 2013;122:3599-606.

66. Groves FD, Linet MS, Travis LB, Devesa SS. Cancer surveillance series: non-Hodgkin's lymphoma incidence by histologic subtype in the United States from 1978 through 1995. J Natl Cancer Inst. 2000;92:1240-51.

67. Lee JH, Lee JH, Yoo DS, Kang H, Kim GM, Park HJ, et al. Characteristics of primary cutaneous lymphoma according to WHO-EORTC classification in Korea. Clin Exp Dermatol. 2013;38:457-63.

68. Park JH, Shin HT, Lee DY, Lee JH, Yang JM, Jang KT, et al. World Health Organization-European Organization for Research and Treatment of Cancer classification of cutaneous lymphoma in Korea: a retrospective study at a single tertiary institution. J Am Acad Dermatol. 2012;67:1200-9.

69. Fujita A, Hamada T, Iwatsuki K. Retrospective analysis of 133 patients with cutaneous lymphomas from a single Japanese medical center between 1995 and 2008. J Dermatol. 2011;38:524-30.

70. Yasukawa K, Kato N, Kodama K, Hamasaka A, Hata H. The spectrum of cutaneous lymphomas in Japan: a study of 62 cases based on the World Health Organization Classification. J Cutan Pathol. 2006;33:487-91.

71. Bradford PT, Devesa SS, Anderson WF, Toro JR. Cutaneous lymphoma incidence patterns in the United States: a populationbased study of 3884 cases. Blood. 2009;113:5064-73.

72. Willemze R, Jaffe ES, Burg G, Cerroni L, Berti E, Swerdlow SH, et al. WHO-EORTC classification for cutaneous lymphomas. Blood. 2005;105:3768-85.

73. Gaulard P, Berti E, Willemze R, Jaffe ES. Primary cutaneous peripheral T-cell lymphomas, rare subtypes. In: Swerdlow SH, Campo E, Harris NL, Jaffe ES, Pileri S, Stein H, et al., editors. WHO classification of tumours of haematopoietic and lymphoid tissues. Lyon: WHO; 2008. p. 302-5.

74. Rodriguez-Pinilla SM, Ortiz-Romero PL, Monsalvez V, Tomas IE, Almagro M, Sevilla A, et al. TCR-gamma expression in primary cutaneous T-cell lymphomas. Am J Surg Pathol. 2013;37:375-84.

75. Garcia-Herrera A, Song JY, Chuang SS, Villamor N, Colomo L, Pittaluga $\mathrm{S}$, et al. Nonhepatosplenic gammadelta T-cell lymphomas represent a spectrum of aggressive cytotoxic T-cell lymphomas with a mainly extranodal presentation. Am J Surg Pathol. 2011;35:1214-25.
76. Yamamoto-Sugitani M, Kuroda J, Shimura Y, Nagoshi H, Chinen Y, Ohshiro M, et al. Comprehensive cytogenetic study of primary cutaneous gamma-delta T-cell lymphoma by means of spectral karyotyping and genome-wide single nucleotide polymorphism array. Cancer Genet. 2012;205:459-64.

77. Nofal A, Abdel-Mawla MY, Assaf M, Salah E. Primary cutaneous aggressive epidermotropic CD8+ T-cell lymphoma: proposed diagnostic criteria and therapeutic evaluation. J Am Acad Dermatol. 2012;67:748-59.

78. Hagiwara M, Takata K, Shimoyama Y, Yamamoto K, Takahashi E, Asano N, et al. Primary cutaneous T-cell lymphoma of unspecified type with cytotoxic phenotype: clinicopathological analysis of 27 patients. Cancer Sci. 2009;100:33-41.

79. Gomez Vazquez M, Navarra Amayuelas R. Primary cutaneous aggressive epidermotropic CD8 $+\mathrm{T}$ cell lymphoma with a chronic and indolent course. Is this different from peripheral $\mathrm{T}$ cell lymphoma? Dermatol Online J. 2012;18:11.

80. Beltraminelli H, Leinweber B, Kerl H, Cerroni L. Primary cutaneous CD4+ small-/medium-sized pleomorphic T-cell lymphoma: a cutaneous nodular proliferation of pleomorphic $\mathrm{T}$ lymphocytes of undetermined significance? A study of 136 cases. Am J Dermatopathol. 2009;31:317-22.

81. Grogg KL, Jung S, Erickson LA, McClure RF, Dogan A. Primary cutaneous CD4-positive small/medium-sized pleomorphic T-cell lymphoma: a clonal T-cell lymphoproliferative disorder with indolent behavior. Mod Pathol. 2008;21:708-15.

82. Quintanilla-Martinez L, Jansen PM, Kinney MC, Swerdlow SH, Willemze R. Non-mycosis fungoides cutaneous T-cell lymphomas: report of the 2011 Society for Hematopathology/European Association for Haematopathology workshop. Am J Clin Pathol. 2013;139:491-514.

83. Rodriguez Pinilla SM, Roncador G, Rodriguez-Peralto JL, Mollejo M, Garcia JF, Montes-Moreno S, et al. Primary cutaneous CD4+ small/medium-sized pleomorphic T-cell lymphoma expresses follicular T-cell markers. Am J Surg Pathol. 2009;33:81-90.

84. Cetinozman F, Jansen PM, Willemze R. Expression of programmed death-1 in primary cutaneous CD4-positive small/ medium-sized pleomorphic T-cell lymphoma, cutaneous pseudoT-cell lymphoma, and other types of cutaneous T-cell lymphoma. Am J Surg Pathol. 2012;36:109-16.

85. Cho EY, Kim KH, Kim WS, Yoo KH, Koo HH, Ko YH. The spectrum of Epstein-Barr virus-associated lymphoproliferative disease in Korea: incidence of disease entities by age groups. J Korean Med Sci. 2008;23:185-92.

86. Ng SB, Lai KW, Murugaya S, Lee KM, Loong SL, Fook-Chong $S$, et al. Nasal-type extranodal natural killer/T-cell lymphomas: a clinicopathologic and genotypic study of 42 cases in Singapore. Mod Pathol. 2004; 17:1097-107.

87. Pongpruttipan T, Sukpanichnant $\mathrm{S}$, Assanasen T, Wannakrairot $\mathrm{P}$, Boonsakan P, Kanoksil W, et al. Extranodal NK/T-cell lymphoma, nasal type, includes cases of natural killer cell and alphabeta, gammadelta, and alphabeta/gammadelta T-cell origin: a comprehensive clinicopathologic and phenotypic study. Am J Surg Pathol. 2012;36:481-99.

88. Karube K, Nakagawa M, Tsuzuki S, Takeuchi I, Honma K, Nakashima Y, et al. Identification of FOXO3 and PRDM1 as tumor-suppressor gene candidates in NK-cell neoplasms by genomic and functional analyses. Blood. 2011;118:3195-204.

89. Ng SB, Selvarajan V, Huang G, Zhou J, Feldman AL, Law M, et al. Activated oncogenic pathways and therapeutic targets in extranodal nasal-type NK/T cell lymphoma revealed by gene expression profiling. J Pathol. 2011;223:496-510.

90. Iqbal J, Weisenburger DD, Chowdhury A, Tsai MY, Srivastava G, Greiner TC, et al. Natural killer cell lymphoma shares strikingly similar molecular features with a group of non-hepatosplenic 
gammadelta T-cell lymphoma and is highly sensitive to a novel aurora kinase A inhibitor in vitro. Leukemia. 2011;25:348-58.

91. Quintanilla-Martinez L, Kimura H, Jaffe ES. EBV-positive T-cell lymphoproliferative disorders of childhood. In: Swerdlow SH,
Campo E, Harris NL, Jaffe ES, Pileri S, Stein H, et al., editors. WHO classification of tumours of haematopoietic and lymphoid tissues. Lyon: WHO; 2008. p. 278-80. 